\title{
Formal and informal appropriation mechanisms: The role of openness and innovativeness
}

Citation for published version (APA):

Zobel, A-K., Lokshin, B., \& Hagedoorn, J. (2017). Formal and informal appropriation mechanisms: The role of openness and innovativeness. Technovation, 59(1), 44-54.

https://doi.org/10.1016/j.technovation.2016.10.001

Document status and date:

Published: 01/01/2017

DOI:

10.1016/j.technovation.2016.10.001

Document Version:

Publisher's PDF, also known as Version of record

Document license:

Taverne

Please check the document version of this publication:

- A submitted manuscript is the version of the article upon submission and before peer-review. There can be important differences between the submitted version and the official published version of record.

People interested in the research are advised to contact the author for the final version of the publication, or visit the DOI to the publisher's website.

- The final author version and the galley proof are versions of the publication after peer review.

- The final published version features the final layout of the paper including the volume, issue and page numbers.

Link to publication

\footnotetext{
General rights rights.

- You may freely distribute the URL identifying the publication in the public portal. please follow below link for the End User Agreement:

www.umlib.nl/taverne-license

Take down policy

If you believe that this document breaches copyright please contact us at:

repository@maastrichtuniversity.nl

providing details and we will investigate your claim.
}

Copyright and moral rights for the publications made accessible in the public portal are retained by the authors and/or other copyright owners and it is a condition of accessing publications that users recognise and abide by the legal requirements associated with these

- Users may download and print one copy of any publication from the public portal for the purpose of private study or research.

- You may not further distribute the material or use it for any profit-making activity or commercial gain

If the publication is distributed under the terms of Article $25 \mathrm{fa}$ of the Dutch Copyright Act, indicated by the "Taverne" license above, 


\title{
Formal and informal appropriation mechanisms: The role of openness and innovativeness
}

\author{
Ann-Kristin Zobel ${ }^{\mathrm{a}}$, Boris Lokshin ${ }^{\mathrm{b}}$, John Hagedoorn ${ }^{\mathrm{c}, \mathrm{d}, *}$ \\ a Department of Management, Technology and Economics, ETH Zürich, 8092 Zürich, Switzerland \\ b Department of Organization \& Strategy, School of Business and Economics, Maastricht University, 6200 MD Maastricht, The Netherlands \\ ${ }^{\mathrm{c}}$ School of Management, Royal Holloway University of London, TW20 OEX Egham, Surrey, United Kingdom \\ d UNU-MERIT, 6211 AX Maastricht, The Netherlands
}

\section{A R T I C L E I N F O}

\section{Keywords:}

Appropriation mechanisms

Formal appropriation

Informal appropriation

External search openness

Incremental innovators

Radical innovators

\begin{abstract}
A B S T R A C T
This paper analyses how firms' degree of openness and innovativeness influence their use of formal and informal appropriation mechanisms. Patents, trademarks, copyrights, and design rights are formal appropriation mechanisms. Secrecy, lead-time, and complexity are examples of informal appropriation mechanisms. Both external search breadth and depth are positively associated with firms' use of informal appropriation mechanisms, while only external search breadth is positively associated with formal appropriation mechanisms. Firms' degree of radical (incremental) innovation orientation is negatively (positively) associated with their use of formal appropriation mechanisms. Analysis of the joint impact of openness and innovativeness, suggests that for radical innovators it is external search breadth (rather than depth) that has a positive association with the use of informal appropriation mechanisms. In contrast, for radical innovators external search depth (rather than breadth) is associated with the use of formal appropriation mechanisms. For incremental innovators, external search breadth (rather than depth) is associated with the use of both formal and informal appropriation mechanisms.
\end{abstract}

\section{Introduction}

This study examines how firms' degree of openness and innovativeness is individually and jointly associated with their use of formal and informal appropriation mechanisms. Empirical work by Cohen et al. (2000) and Levin et al. (1987) already established that both formal and informal appropriation mechanisms are relevant for protecting the innovative endeavours of firms. Formal appropriation mechanisms, based on intellectual property (patents, trademarks, copyrights, and design rights), give innovating firms time-limited rights to exploit their discoveries, inventions, and new designs. These formal appropriation mechanisms create incentives for firms to re-invest in innovations, new technologies, and to diffuse new products based on innovations that are protected by law. In addition, firms can use informal appropriation mechanisms, such as secrecy, lead-time, and complexity (Neuhaeusler, 2012; Hall et al., 2014). In general, informal appropriation mechanisms are not protected by law, although in particular trade secrets can be enforced through confidentiality contracts and non-disclosure contracts. Lead-time and complexity are based on confidential and usually tacit knowledge that enables innovating firms either to benefit from first mover advantages through early commercialization of innovations or to benefit from complex new products and processes that are difficult for other firms to imitate within a short period of time.

Given the increasing strategic importance of such appropriation mechanisms (e.g. Pisano and Teece, 2007; Somaya, 2012), recent research has begun to investigate factors that influence firms' use of formal and informal appropriation mechanisms (see James et al., 2013 for a comprehensive review of that literature). For instance, the degree of patenting has been shown to be influenced by industry-level conditions (Cohen et al., 2000), firm size (Arundel and Kabla, 1998), and capital intensity (Hall and Ziedonis, 2001). Likewise, there is some preliminary understanding of industry- and firm-level factors that are associated with the cost of utilizing secrecy as an appropriation mechanism, such as competitive conditions (James et al., 2013), or the complexity of knowledge residing inside the firm (Liebeskind, 1997). A recent study by Neuhaeusler (2012) investigates to what extent firm characteristics, such as size and industry affiliation influence the preference for formal and informal appropriation mechanisms. Despite this evidence, less is known about how firms'

\footnotetext{
* Corresponding author at: School of Management, Royal Holloway University of London, TW20 0EX Egham, Surrey, United Kingdom.

E-mail addresses: azobel@ethz.ch (A.-K. Zobel), b.lokshin@maastrichtuniversity.nl (B. Lokshin), john.hagedoorn@rhul.ac.uk, j.hagedoorn@maastrichtuniversity.nl (J. Hagedoorn).
} 
innovation activities are associated with the implementation of formal as well as informal appropriation mechanisms. This is surprising, since appropriation mechanisms are relevant tools for translating innovation activities into sources of competitive advantage (Milesi et al., 2013) and are, therefore, likely to be influenced by characteristics of the innovation process.

This paper addresses this gap by investigating how the degrees of openness and newness of firms' innovation activities influence firms' use of both formal and informal appropriation mechanisms. Appropriability conditions are no longer to be considered as primarily exogenously given and as such firms can influence the characteristics of their appropriability context by means of specific strategies and behaviours (Pisano, 2006; Pisano and Teece, 2007; HurmelinnaLaukkanen, 2011; Neuhaeusler, 2012; Milesi et al., 2013). Innovative activities of firms involve resource-intensive processes to create new knowledge and to find commercially viable combinations of knowledge or technology. As new knowledge is created and combined, issues of protecting these innovative activities via appropriation mechanisms become particularly pertinent. Milesi et al. (2013) already suggested that characteristics of the innovation process influence firms' choices as to how to appropriate innovation profits. They argue that since the innovation process is unpredictable, the implementation of appropriation strategies is an ex-post decision or, in the best case, arises at the same time as the innovation process. This study adds to this prior work by investigating how two specific characteristics of the innovation process -the degree to which it is open and the degree to which it is radical versus incremental - influence the implementation of both formal and informal appropriation mechanisms. As such this study follows prior research in suggesting that characteristics of the innovation process impact firms' use of appropriation mechanisms. Since both independent and dependent variables are strategic choice variables that are not exogenous (see also Laursen and Salter, 2014) the research questions and hypotheses in this paper are formulated in terms of 'associations' rather than causal effects.

The concept of open innovation suggests that firms make greater use of external knowledge and increasingly collaborate with a variety of external partners (Chesbrough, 2003; Mortara and Minshall, 2011). In particular, firms search more broadly and deeply across different types of external knowledge sources (e.g. Laursen and Salter, 2006; Chiang and Hung, 2010; Drechsler and Natter, 2010; Köhler et al., 2012; Garriga et al., 2013). An obvious risk associated with such openness lies in the fact that resources are made available for others to exploit. This might make it more difficult to protect the innovative efforts of firms and to capture benefits that accrue from collaborative and shared innovative efforts (Helfat and Quinn, 2006; Dahlander and Gann, 2010; Huizingh, 2011). Securing certain legal rights in terms of formal appropriation mechanisms as well as making use of informal alternative forms of appropriation seem particularly critical for firms that are open in their innovative efforts but that also want to survive competitive pressures created by actions of other firms (Hurmelinna et al., 2007). Hence, the first research question refers to the influence of openness in innovation - in terms of external search breadth and depth - on the use of both formal and informal appropriation mechanisms.

Also, innovative activities of firms, whether they stem from traditional closed innovative activities or from open innovation, demonstrate different degrees of newness (Schmidt and Calantone, 1998). Radical innovative activities involve products that are new to the market (Dewar and Dutton, 1986) including, for instance, new product lines and product line extensions with new technology (Garcia and Calantone, 2002). Conversely, incremental innovative activities involve the adaptation, refinement and enhancement of products, thereby largely building on existing common technological knowledge (Dewar and Dutton, 1986). While they are usually new to the firm, products from incremental innovative activities only offer minor improvements for markets (Garcia and Calantone, 2002). The degree to which firms have a more or less incremental innovation orientation, or alternatively a more or less radical innovation orientation is likely to be related with their strategies for protecting these innovative efforts (see also Hall et al., 2014). One the one hand, as firms create more new and advanced, i.e. distant, knowledge and hence, develop more radical innovations, they may be hesitant to disclose this distant knowledge via the use of a large number of formal appropriation mechanisms. Alternatively, the distant nature of this knowledge may make the use of informal appropriation mechanisms, such as secrecy, more valuable for these firms. On the other hand, firms with a higher incremental innovation orientation may derive little benefits from informal appropriation mechanisms that can hardly protect innovations that closely build on existing knowledge. Instead, the higher their incremental innovation orientation, the more these firms may protect their incremental knowledge via formal appropriation mechanisms. Hence, the second research question is: to what extent does the degree of innovativeness of firms influence their use of formal as well as informal appropriation mechanisms?

Finally, firms are expected to consider both characteristics of their overall innovation strategies. i.e., their openness and their degree of innovativeness, in using formal and informal appropriation mechanisms. Depending on firms' overall degree of innovativeness, external search breadth and depth may have differential impact on their appropriation strategies. For instance, for firms with a more incremental innovation orientation, external search breadth poses a higher appropriation risk than external search depth, as the incremental nature of the produced knowledge is easily accessible by a broad range of external partners. On the contrary, for firms with a more radical innovation orientation, external search depth (as opposed to breadth) leads to higher appropriation risk, since in-depth search with partners increases the risk of knowledge spill-overs by reducing the distance of the knowledge underlying the more radical innovations. Accordingly, a third research question deals with the joint impact of the two aspects of firms' overall innovation strategies, i.e., their openness and innovativeness, on appropriation mechanisms. In sum, the contribution of this study is a more detailed investigation of the direct and interactive impact of the degree of openness (in terms of external search breadth and depth) and the degree of innovativeness (in terms of radical versus incremental innovators) on formal and informal appropriation mechanisms.

\section{Hypotheses}

\subsection{Openness in innovation and formal and informal appropriation} mechanisms

As suggested by previous literature (e.g. Laursen and Salter, 2006; Chiang and Hung, 2010; Drechsler and Natter, 2010; Köhler et al., 2012; Garriga et al., 2013; Salge et al., 2013), the degree of openness in innovation of firms can be conceptualized in terms of the breadth and depth of their external search strategies. In particular, external search breadth refers to the diversity of external sources of knowledge for innovative activities (different categories of firms, universities, and research or technology institutions, as well as other specialized sources such as conferences or trade fairs). External search depth is understood in terms of the importance of these external sources of knowledge. Both external search breadth and depth can then characterize a firm's degree of openness in its innovation process. A number of prior contributions already suggest that in the context of open innovation the systematic use of appropriation mechanisms is relevant as it ensures that firms can still capture value from their innovative activities while they search extensively across their external partners (Sandulli and Chesbrough, 2009; Laursen and Salter, 2014; Hagedoorn and Zobel, 2015; Zobel et al., 2016).

First, formal appropriation mechanisms, such as patents, trademarks, copyrights, and design rights provide a certain degree of knowledge protection, such that the intangible assets of firms are 
difficult to imitate or appropriate by their partner firms (Dubiansky, 2006; Graham and Mowery, 2006; Pisano and Teece, 2007). The same logic applies for open innovation activities involving a non-firm partner, such as a university or research institute, where a firm faces the inherent risk that its partner also works with competing firms currently or in the future - that are potential imitators of its innovative efforts. Furthermore, formal appropriation mechanisms prevent potential free riding behaviour of all sorts of open innovation partners and secure transactions and exchanges of knowledge and technology (Pénin et al., 2011). Consequently, the more broadly and deeply firms search across a range of external partners, the more they are expected to use formal appropriation mechanisms to protect their innovative capabilities and outputs.

Prior literature also reveals a range of other motives for using formal appropriation mechanisms in the context of open innovation. Intellectual property (e.g. patents) can be used for determining the scope of joint innovation efforts or as a signalling device for indicating the firm's innovative capability to potential partners (Alexy et al., 2009; Hsu and Ziedonis, 2013). It can also help to structure and coordinate R \& D collaborations by providing an improved and more transparent basis for negotiation (Pénin et al., 2011). Furthermore, the existence of formal appropriation mechanisms facilitates knowledge sharing as this implies that there is relevant knowledge in codified form that can be more easily transferred between partners, at the same time providing a shield under which knowledge is shared during the exchange (Hurmelinna et al., 2007; Alexy et al., 2009; Kani and Motohashi, 2012). Jointly, these underlying mechanisms suggest that keeping control over knowledge and technology via formal appropriation mechanisms is critical for firms that engage in open innovation and thereby, point to a positive association between external search breadth/depth and the degree to which firms implement formal appropriation mechanisms.

Second, previous studies show that firms also use informal mechanisms, such as secrecy, lead-time, and complexity, to protect their innovative activities and outputs (James et al., 2013; Hall et al., 2014). Similarly, prior research indicates that firms that operate in the context of open innovation not only pay attention to knowledge protection through formal appropriation mechanisms but they also consider informal appropriation mechanisms as an element of their overall appropriation strategy (Luoma et al., 2010; Huizingh, 2011; Laursen and Salter, 2014; Hagedoorn and Zobel, 2015). As firms search broadly and deeply across external partners they may not want to disclose all parts of their knowledge base. As such, they may increasingly hinder the release and transfer of new ideas and technologies by means of informal mechanisms, such as secrecy (Hall et al., 2014). Therefore, the degree of openness of firms is, in general, also associated with an increased use of informal appropriation mechanisms.

In sum, there is a positive association between the degree of openness and firms' use of both formal and informal appropriation mechanisms. Since prior research has already investigated the association between openness in innovation and firms' degree of appropriation (Laursen and Salter, 2014; Hagedoorn and Zobel, 2015), the study at hand presents these associations as baseline hypotheses. Yet, departing from prior research the hypotheses are split into an (a) and (b) part that enables a parallel analysis of both formal and informal appropriation mechanisms. Furthermore, the hypotheses distinguish between external search breadth and depth in order to capture both dimensions of a firm's openness in innovation. These differentiations in the baseline hypotheses will be important for studying the third research question that refers to how external search breadth and depth influence formal and informal appropriation mechanisms differently, depending on whether firms are radical or incremental innovators. Hence, the following baseline hypotheses are stipulated:

H1. Firms' external search breadth has a positive association with their use of (a) formal appropriation mechanisms and (b) informal appropriation mechanisms.

H2. Firms' external search depth has a positive association with their use of (a) formal appropriation mechanisms and (b) informal appropriation mechanisms.

\subsection{Innovativeness and formal and informal appropriation mechanisms}

Given the differentiation in the innovation literature between incremental and radical innovators, the question emerges as to what extent, more or less incremental or alternatively more or less radical innovators use formal and informal appropriation mechanisms to protect their new products. The differentiation between incremental and radical innovative activities is less of a dichotomy rather than a continuum where innovative activities can be characterized in terms of their relative incremental or radical nature, which suggests various degrees of innovative 'newness' (Garcia and Calantone, 2002). Similarly, firms, as the main carriers of these innovative activities, can be categorized as incremental or radical innovators where it has to be recognized that the nature of their role as incremental or radical innovators is rather of a relative than a dichotomous nature. In other words, firms can be seen as more or less incremental innovators or more or less radical innovators, depending on the degree to which they introduce new products to their own output or also introduce new products that are new to the market at large.

In an interesting theoretical contribution, Anton and Yao (2004) suggest that firms characterized as radical innovators rely less on formal appropriation mechanisms than other firms that can be found more on the incremental side of innovativeness. Their model implies that formal appropriation mechanisms, based on intellectual property, are not perfect and that the disclosure of the actual innovation(s) through intellectual property creates an opportunity for other firms to re-engineer or re-design 'alternative' products (see also Langinier, 2005; Magazzini et al., 2009; Somaya, 2012). Somewhat counterintuitively, their model suggests that the more innovative, i.e. the more firms act as radical innovators, the larger the innovative distance to other firms, the less likely these firms prefer to use formal appropriation mechanisms that requires disclosure. These arguments point to a negative association between a firm's radical innovation orientation and its implementation of formal appropriation mechanisms.

For these radical innovators, informal appropriation mechanisms, such as lead-time, secrecy, and complexity, are expected to be more relevant mechanisms to protect their innovative rents as these mechanisms do not require firms to publicly reveal the fundamentals of their radical innovations (Anton and Yao, 2004). Similarly, Zaby (2010) presents a model where firms with a 'technological head start', i.e. with considerable innovative distance to others, show a lower propensity to use formal appropriation mechanisms and prefer secrecy to avoid the risks of disclosure. Furthermore, informal appropriation mechanisms might be useful for these radical innovators as it entails greater flexibility as informal appropriation mechanisms can be applied to a larger range of knowledge types, such as non-codified, tacit, and early stage knowledge. As noted by Hannah (2005), non-codified, tacit, and early stage knowledge might be particularly relevant in the context of radical innovations. Thus, the more innovators can be considered radical, the more relevant do informal appropriation mechanisms become for protecting their innovative capabilities and innovative output as it enables them to maintain flexibility, while not facing risks of disclosure. Taken the above arguments together, hypothesis three suggests that:

H3. Firms' radical innovation orientation has (a) a negative association with their use of formal appropriation mechanisms and (b) a positive association with their use of informal appropriation mechanisms.

For incremental innovators, that largely base their innovative 
activities on existing knowledge, informal appropriation mechanisms provide little or no protection as their new to the firm innovations are based on existing common technological knowledge. In particular, lead time and secrecy are of little relevance for incremental innovators as there is little or no lead time and neither is secrecy relevant when their innovative activities are largely drawn from existing common technological knowledge. As a result, this study assumes a negative association between a firm's incremental innovation orientation and its implementation of informal appropriation mechanisms.

Instead, one can expect that for incremental innovators that introduce improvements to existing products it is important to protect their innovative activities through formal appropriation mechanisms (see also Zaby, 2010). In a perfect world, it would be, of course, difficult for incremental innovators to use formal appropriation mechanisms, such as patents, as their innovative efforts would be too close to the state-of-the-art. However, without entering into the debate about the quality of current intellectual property as an appropriation mechanism, there is increasing evidence on the decline of the quality of formal appropriation mechanisms (in particular patents) through which firms apply for intellectual property that is relatively close to the state-of-theart or rather incremental (see e.g. Bessen and Meurer, 2008). Therefore, for these incremental innovators, formal appropriation mechanisms give some protection for innovations that are close to existing technological knowledge. Hence, the more their innovation orientation is incremental in nature, the more they will be inclined to implement a greater number of formal association mechanisms. Hence:

H4. Firms' incremental innovation orientation has (a) a positive association with their use of formal appropriation mechanisms and (b) a negative association with their use of informal appropriation mechanisms.

\subsection{Joint influence of openness and innovativeness on formal and informal appropriation mechanisms}

Prior work suggests that firms' degree of innovativeness and external search openness are intertwined (Köhler et al., 2012). This points to the importance of studying potential interactive impact of the degree of innovativeness and external search openness on firms' use of formal and informal appropriation mechanisms. The following section differentiates between incremental and radical innovators and argues to what extent it is their external search breadth or external search depth that influence their use of formal and informal appropriation mechanisms.

\subsubsection{Openness and incremental innovators}

It is relatively simple for partners of firms that are characterized as incremental innovators, i.e., for partners of those firms that base their incremental innovative activities on existing common knowledge, to acquire this knowledge. Given the modest nature of the innovative activities of incremental innovators, the primary risk of unintended knowledge transfer from incremental innovators lies with any interactions through which external parties can easily appropriate this already existing relevant knowledge. With heightened diversity of their interactions with a variety of external parties, which indicates external search breadth, these incremental innovators increasingly face the risk of unintended knowledge transfer to their partners. This augmented risk of knowledge leakage with increasing breadth in openness forces them to increasingly use formal appropriation mechanisms to protect their knowledge from a variety of external parties.

Given the incremental innovative nature of these firms, the depth of their external search activities seems less relevant for their use of formal appropriation mechanisms. Their interactions with external parties builds largely on existing common knowledge which is easily accessible and well-suited for incremental innovation, but for which there is little or no need for in-depth search. Given the common knowledge character of the knowledge exchange activities of incremental innovators, any enhanced search depth will not significantly increase the risk of unintended knowledge leakage. Thus, increasing the depth of external search openness is of little or no relevance and will not impact incremental innovators to further employ formal appropriation mechanisms. Hence, it is expected that for incremental innovators, external search breadth, rather than external search depth, is of a primary concern and as such it is particularly the increasing breadth of the incremental innovator's openness that is expected to impact their use of formal appropriation mechanisms.

Informal appropriation mechanisms, based on secrecy, lead-time, and complexity are, given the common knowledge base of incremental innovators, of little relevance with heightened diversity and intensity of their external search efforts. Furthermore, searching broadly across external parties often involves the transfer of codified knowledge that requires low levels of commitment (Van de Vrande et al., 2006; Garriga et al., 2013). Also in that context, formal appropriation mechanisms are more relevant for protecting this codified knowledge than informal appropriation mechanisms. Given the expected general association between incremental innovativeness and the use of formal appropriation mechanisms (see H2a), complexity, secrecy, and lead-time are less relevant for incremental innovators to protect their innovative rents. Hence, a specific impact of either the increasing external search breadth or depth of incremental innovators on their use of informal appropriation mechanisms is not expected and, therefore, not hypothesized. Hence, the following hypothesis focuses on formal appropriation mechanisms and suggests that:

H5. Increasing external search breadth of incremental innovators is positively associated with their use of formal appropriation mechanisms.

\subsubsection{Openness and radical innovators}

Hypothesis 3b stipulates that, in general, the degree to which firms are characterized as radical innovators has a positive association with their use of informal appropriation mechanisms, such as complexity, lead time, and secrecy. However, while these radical innovators, that develop new technological knowledge that is used to create new to the market innovations, search across their external partners, they might still face the risk of unintended knowledge transfer in the context of certain types of openness in innovation. More particular, in-depth search across external partners will increase the risk of unintended knowledge transfer to others (Gomes-Casseres et al., 2006; Mowery et al., 1998). When firms interact deeply with external parties, both parties typically aim at and are better capable of tapping into more detailed tacit knowledge (Chiang and Hung, 2010; Garriga et al., 2013). This risk of tacit knowledge transfer will make the firm more vulnerable to potential knowledge leakage. The combination of radical innovators and in-depth external search with increased risk of knowledge leakage suggests that it is more appropriate for these firms to use formal appropriation mechanisms, based on intellectual property, to protect their innovative activities.

When these radical innovators search broadly, rather than deeply, they may not be required to refer to such formal means of appropriation. In broad external search patterns, that are superficial, rather than deep, the tacit knowledge of radical innovators is less likely to be accessible by their partners. As such, radical innovators face a lower risk of unintended knowledge transfer when they collaborate broadly and may, therefore, be more hesitant to reveal the fundamentals of their innovations via formal appropriation (see also argumentation leading up to $\mathrm{H} 3 \mathrm{~b}$ ). Hence, it is particularly the external search depth that influences their usage of formal appropriation.

Yet, in the context of external search breadth, informal appropriation mechanisms become increasingly interesting for radical innovators. Compared to in-depth search, just searching broadly across a 
diverse group of partners indicates a lower risk of unintended knowledge transfer for radical innovators. As indicated by previous research, when radical innovators engage in broad rather than in-depth cooperation, their partners cannot easily know which part of the innovator's knowledge will be worth imitating (Haunschild and Miner, 1997; Koput 1997). Furthermore, if partners do not interact deeply with radical innovators, it will be more difficult for these partners to tap into the tacit knowledge of radical innovators (Garriga et al., 2013). In addition, while using informal appropriation mechanisms, such as secrecy, product complexity, and lead-time, radical innovators can make it difficult for their partners to identify and access relevant new knowledge. Under these conditions, when search across external partners is characterized by breadth rather than depth, informal appropriation remains an important mechanism for radical innovators. Thus, external search breadth is more relevant for radical innovators in determining their use of informal appropriation mechanisms. Jointly, this suggests:

H6a. Increasing external search depth of radical innovators is positively associated with their use of formal appropriation mechanisms.

H6b. Increasing external search breadth of radical innovators is positively associated with their use of informal appropriation mechanisms.

\section{Data and methods}

The hypotheses are tested using data from the Dutch Community Innovation Survey (CIS), which is conducted every two years by the Central Bureau of Statistics (CBS) in the Netherlands since 1996. The Dutch CIS is part of the Europe-wide data collection process under the auspices of the European Commission aimed at collecting harmonized data on firm innovation activities in the EU. These data forming a basis for official EU R\&D statistics are collected in accordance with the international guidelines for collecting innovation data from the private sector. The sampling methodology, as well as the harmonized questionnaire, is described in the OECD Oslo Manual (Eurostat and OECD, 2005; OECD, 2005).

CIS is an appropriate data source for the research questions for several reasons. First, CIS is one of the few secondary data sources at the firm level that has a question on the extent to which formal and informal IP are prevalent among firms. The only other source the authors are aware of is the Yale survey (Levin et al., 1987) and a subsequent Carnegie Mellon Survey (CMS) of Research and Development (Cohen et al., 2000). Second, being a database collected and maintained by the Central Bureau of Statistics, CIS has advantages over primary data in that it has a large sample size, broad coverage of industries, and inclusion of different types of firms with respect to their characteristics such as firm size, and R \& D intensity. Hence, the use of these data avoids the oversampling of large firms. Third, for the larger part CIS surveys are compatible across years, an important feature that allows us to use the lagged values of the explanatory variables in the analysis. These aspects of CIS improve the robustness of the inference that can be made from analysing CIS data.

While the set of questions on the use of formal appropriation mechanisms (patents, trademarks, copyrights, and design rights) has been consistently included in several CIS surveys, the questions pertaining to the use of informal appropriation mechanisms (secrecy, lead-time, and product complexity) were included in year 2000 survey only. Hence, the hypotheses on the use of formal and informal appropriation mechanisms are tested using this cross-sectional dataset. Shortcomings of the CIS data and of the approach to the analysis are discussed in the limitations section.

\subsection{Measures}

The first dependent variable, formal appropriation mechanisms, refers to the exclusive privileges granted to owners of a variety of distinct new creations in terms of intangible assets (discoveries, inventions, and new designs). Formal appropriation mechanisms includes patents, trademarks, copyrights, and design rights. The CIS surveys ask whether a focal firm has applied for any of these four formal appropriation mechanisms in the past two years. Using this question, the number of forms of formal appropriation mechanisms a firm had used are summed up.

The second dependent variable, informal appropriation mechanisms, refers to the use of such forms of protection as secrecy, lead time, and product complexity as ways to guard innovations from competitors. The managers of the surveyed firms were asked whether any of these informal appropriation mechanisms were used in the previous two years. Based on the responses to this question, the number of forms of informal appropriation mechanisms a firm had used are summed up.

The first focal independent variable, the external search breadth is a count of the variety of external sources of knowledge used by a firm derived from the CIS surveys. Following Laursen and Salter (2006); Chiang and Hung (2010), and Garriga et al. (2013), market- and institutional-based external sources are included, as well as other specialized sources such as consultants, professional conferences, trade fairs or exhibitions to achieve a better fit with the concept of firms' general search strategies.

Next, the external search depth refers to the actual importance of external sources of knowledge for the innovative activities as stipulated in the CIS surveys. The managers of the sample firms were asked to rate the importance of sources of knowledge used in the innovation activities. Following Laursen and Salter (2006); Chiang and Hung (2010) and Garriga et al. (2013) each of the sources were recoded with value one when a firm reported that it used this source to a high degree and zero in the case of no, low, or medium use of the given source and then the sources were added up.

This study also exploits the CIS question that asks firms to indicate (in percentages) the shares of unmodified, new to the firm, and new to the market products in their total sales. The two latter variables are mutually exclusive and together with the share of unchanged products add up to 100 per cent of firm's sales. This information was used to assess both the degree to which a firm can be categorized as having incremental or radical innovation orientation (for testing hypotheses $\mathrm{H} 3 \mathrm{a}$ and b and $\mathrm{H} 4 \mathrm{a}$ and b), as well as to separate firms into two groups, which allows investigating the impact of breadth and depths of search openness on the use of appropriation mechanisms by incremental versus radical innovators (for testing Hypotheses 5 and $6 \mathrm{a}$ and $\mathrm{b}$ ).

Regarding the degree of innovative orientation, the variable share of incremental innovation refers to the share of new to the firm only products, while the variable share of radical innovation refers to the firm's share of new-to-the-market products in total sales. Higher values of these variables correspond to a higher degree to which firms have incremental or radical innovation orientation. Furthermore, to distinguish between these two groups of firms, radical innovators are defined as firms that have a positive share of innovative sales from new-to-the-market products and services. Incremental innovators are firms that generated (part of) their sales from significantly improved products and services that were new-to-the-firm, and that have a zero share of sales generated from products that were new-to-the-market.

A first control variable is $R \& D$ intensity (the ratio of internal $\mathrm{R} \& \mathrm{D}$ expenditures to total sales). More R \& D-intensive firms are also more likely to extensively use appropriation mechanisms (Hall et al., 2014). The analysis also controls for firm size. Larger firms have more abundant resources and higher R\&D intensity (e.g. Narula, 2004; Muscio, 2007) and may, therefore, find it less problematic to handle multiple innovation objectives (Freeman and Soete, 1997) and manage 
multiple technology collaborations (Frankort et al., 2012). Moreover, size may influence firms' preferences for different forms of appropriation, particularly in the context of collaborative innovation activities. For instance, while SMEs may make greater use of non-internal R \& D sources (e.g. Lee et al., 2010), they also tend to be more concerned about their loss of technological assets and competencies (Narula, 2004). As a result, in the context of searching broadly and deeply across external partners, SMEs may be more careful in selecting formal and informal appropriation mechanisms in order to mitigate their vulnerability due to smaller size. Size is measured as the logarithm of the number of employees. R \& D intensity and firm size are taken from the $(t-2)$ survey. A further control variable refers to whether the firm is part of a larger (domestic) group. Firms that are part of a larger group may draw on group financial, legal, and technological resources that may lead to a higher propensity to use appropriation mechanisms (Narula and Zanfei, 2003). Finally, the analysis includes a set industry dummies (14 at the 2-digit industry level) as the need for formal appropriation mechanisms may differ across industries and across years (Hall et al., 2014).

\subsection{Analysis}

The final dataset includes 1133 innovating firms observed in both the 1998 and 2000 surveys operating in a wide range of industries. For each set of analyses, two types of possible biases are considered. The first important issue is selection bias that may potentially arise from the fact that not all firms are 'innovators' according to the Oslo manual definition and if not, do not fill in the major part of the questionnaire. One consequence of this selection is that the variable for the sales share of innovative products contains zeroes because some R \& D performers are non-product innovators or are non-innovators altogether. There are about $35 \%$ of such firms in the sample. Self-selection, if not accounted for, may bias the results. To address this bias, the selection correction can be included in the regression as an additional covariate. To this end, the analysis followed the Heckman two-step procedure by first running a probit regression to estimate the likelihood of having nonzero values of sales of innovative products and derived from it an inverse Mill's ratio (IMR), which was then introduced in the secondstage regression model to explain the use of appropriation mechanisms. For the first stage models information on firm's age, its size (number of employees) and industry dummies was used at the 2-digit NAICS level as well as location dummies at the province level. This is justified by the differences among provinces with respect to the extent of innovation-related activities.

The endogeneity of the breadth and depth variables is the second issue that requires careful consideration. Endogeneity can be of some concern since a manager's decisions to use open innovation strategies may be endogenous to the extent to which a firm's innovative activities are protected. This concern is addressed by projecting depth and breadth on the variables that are correlated with the endogenous variables but do not directly lead to changes in the measures for appropriation mechanisms. Due to the closed nature of the survey, this study is constrained in its choice of instruments to those available within the questionnaire. The first set of instruments taken from the t-2 survey captures factors hampering the innovation process of the firm, potentially pushing the firm to use open innovation strategies (Drechsler and Natter, 2012). This is also consistent with the management literature perspective on the various motivations for technology partnering. Risk constraint catches limitations caused by uncertain market conditions, organizational constraint captures bottlenecks that relate to firm's shortage of qualified (R\&D) personnel, and cost constraint refers to (forbiddingly) high costs faced by a firm in the innovation activities. As additional instrument, firm age, is included since older firms tend to be more experienced and will have wellestablished routines in place (Nelson and Winter, 1982; March, 1988), also specifically geared to external search activities, which may positively affect their propensity to engage in open innovation. On the other hand, well-established routines and abundant experience may also make firms become more self-reliant (Tidd et al., 2005), which reduces their propensity to be engaged in external search. Finally, eleven region (province) dummies were included as the opportunity for external search arising from, for instance, differences with regard to innovation activity or clustering varies systematically across regions. This estimation applied the Generalized Method of Moments (GMM) method using robust (heteroskedastic-consistent) standard errors, since the White test rejects the assumption of homoscedasticity at 10 per cent. The GMM estimator has been shown to produce more efficient estimates than the traditional IV/2SLS estimator (e.g., Stock and Wright, 2000; Baum et al., 2003).

\section{Empirical results}

Table 1 provides descriptive statistics. It also presents bivariate correlations between the variables used in the estimation. The correlation between the two focal variables, external search depth and breadth is moderate, 0.23 , and does not prevent identification of the two effects. The remaining correlations are low to moderate in almost all cases, suggesting limited issues of multicollinearity.

Table 2 reports the percentage of firms, by industry that used formal and informal appropriation mechanisms. Overall, variation across all industries in the use of the two types of protection is somewhat limited. On average, 51.63 per cent of firms relied on informal appropriation mechanisms and 34.86 per cent of firms applied formal appropriation mechanisms. In addition, lead time is the most popular informal appropriation mechanism, which was used by 75.56 per cent of the firms that used informal appropriation mechanisms, followed by product complexity (42.05 per cent) and secrecy (34.19 per cent). 10.94 per cent of firms used all three informal appropriation mechanisms and 45.64 per cent of firms that used informal appropriation mechanisms also used formal appropriation mechanisms.

Table 3 presents the empirical results of the instrumental variables GMM regression models regarding the use of the formal appropriation mechanisms, relevant for hypotheses $1 \mathrm{a}, 2 \mathrm{a}, 3 \mathrm{a}, 4 \mathrm{a}, 5$, and $6 \mathrm{a}$, see

Table 1

Descriptive statistics and pairwise correlations, 1133 firms.

\begin{tabular}{|c|c|c|c|c|c|c|c|c|c|c|c|c|}
\hline Variables & Mean & S.D. & Min & Max & $\mathbf{1}$ & 2 & 3 & 4 & 5 & 6 & 7 & 8 \\
\hline 1. Informal appropriation mechanisms & 0.78 & 0.90 & 0 & 3 & & & & & & & & \\
\hline 2. Formal appropriation mechanisms & 0.52 & 0.83 & 0 & 4 & 0.25 & & & & & & & \\
\hline 3. External search depth & 0.20 & 0.47 & 0 & 4 & 0.14 & 0.11 & & & & & & \\
\hline 4. External search breadth & 0.76 & 2.01 & 0 & 8 & 0.27 & 0.28 & 0.23 & & & & & \\
\hline 5. Share of radical innovation, $\%$ & 5.58 & 12.50 & 0 & 90 & 0.17 & 0.07 & 0.06 & 0.15 & & & & \\
\hline 6. Share of incremental innovation, $\%$ & 24.23 & 24.99 & 0 & 100 & 0.22 & 0.18 & 0.10 & 0.16 & 0.52 & & & \\
\hline 7. R\& D intensity, \% & 1.58 & 5.37 & 0 & 85 & 0.19 & 0.15 & 0.05 & 0.18 & 0.09 & 0.15 & & \\
\hline 8. Firm size (log) & 4.60 & 1.22 & 0 & 10.02 & 0.21 & 0.26 & 0.06 & 0.25 & 0.06 & 0.09 & 0.17 & \\
\hline 9. Part of a group & 0.77 & 0.42 & 0 & 1 & 0.09 & 0.12 & 0.01 & 0.04 & 0.04 & 0.09 & 0.05 & 0.26 \\
\hline
\end{tabular}


Table 2

Firms' use of formal and informal appropriation mechanisms across industries.

\begin{tabular}{|c|c|c|c|c|}
\hline Industry (SIC code) & $\begin{array}{l}\text { Percentage of firms that use } \\
\text { formal mechanisms }\end{array}$ & $\begin{array}{l}\text { Average number of formal } \\
\text { mechanisms used }\end{array}$ & $\begin{array}{l}\text { Percentage of firms that use } \\
\text { informal mechanisms }\end{array}$ & $\begin{array}{l}\text { Average number of informal } \\
\text { mechanisms used }\end{array}$ \\
\hline Extraction, mining (10) & 26.7 & 1.3 & 46.7 & 1.1 \\
\hline Food, beverages, and tobacco $(15,16)$ & 34.8 & 1.5 & 66.3 & 1.5 \\
\hline Textile, apparel and leather $(17,19)$ & 39.4 & 1.1 & 51.5 & 1.6 \\
\hline Paper and paper products, wood (21) & 30.2 & 1.5 & 46.5 & 1.5 \\
\hline Printing and publishing (22) & 27.5 & 2.0 & 30.4 & 1.5 \\
\hline Oil (23) & 30.0 & 2.0 & 60.0 & 2.0 \\
\hline Chemicals and pharmaceuticals (24) & 49.4 & 1.3 & 61.6 & 1.7 \\
\hline Rubber products and plastics (25) & 40.0 & 1.7 & 65.5 & 1.6 \\
\hline Basic metals (27) & 38.1 & 1.5 & 66.7 & 1.7 \\
\hline Fabricated metal products (28) & 30.3 & 1.4 & 54.6 & 1.3 \\
\hline Machines and equipment (29) & 48.6 & 1.6 & 70.5 & 1.5 \\
\hline Office machinery (30) & 50.6 & 1.6 & 57.1 & 1.6 \\
\hline $\begin{array}{l}\text { Motor vehicles, other transport } \\
\quad \text { equipment }(34,35)\end{array}$ & 42.9 & 1.5 & 41.1 & 1.3 \\
\hline Furniture manufacturing, n.e.c. (36) & 40.6 & 1.6 & 51.3 & 1.4 \\
\hline Other (40) & 20.8 & 1.3 & 35.1 & 1.5 \\
\hline Average & 34.9 & 1.5 & 51.6 & 1.5 \\
\hline
\end{tabular}

Table 3

Instrumental variables analysis of firms' use of formal appropriation mechanisms.

\begin{tabular}{|c|c|c|c|}
\hline & $\begin{array}{l}\text { Model 1 } \\
\text { All firms } \\
\text { H1a, H2a, } \\
\text { H3a, H4a }\end{array}$ & $\begin{array}{l}\text { Model } 2 \\
\text { Radical } \\
\text { innovators } \mathrm{H} 6 \mathrm{a}\end{array}$ & $\begin{array}{l}\text { Model } 3 \\
\text { Incremental } \\
\text { innovators } \mathrm{H} 5\end{array}$ \\
\hline $\begin{array}{l}\text { External search } \\
\text { breadth }\end{array}$ & $\begin{array}{l}0.248^{* * * *} \\
(0.090)\end{array}$ & $\begin{array}{l}0.080 \\
(0.106)\end{array}$ & $\begin{array}{l}0.234^{* * * *} \\
(0.088)\end{array}$ \\
\hline $\begin{array}{l}\text { External search } \\
\text { depth }\end{array}$ & $\begin{array}{l}0.152 \\
(0.444)\end{array}$ & $\begin{array}{l}1.106^{* * * *} \\
(0.415)\end{array}$ & $\begin{array}{l}-0.412 \\
(0.492)\end{array}$ \\
\hline $\begin{array}{l}\text { Share of } \\
\text { incremental } \\
\text { innovation }\end{array}$ & $\begin{array}{l}0.280^{* * *} \\
(0.137)\end{array}$ & $\begin{array}{l}0.282 \\
(0.215)\end{array}$ & $\begin{array}{l}0.255 \\
(0.199)\end{array}$ \\
\hline $\begin{array}{c}\text { Share of radical } \\
\text { innovation }\end{array}$ & $\begin{array}{l}-0.599^{* * *} \\
(0.259)\end{array}$ & $\begin{array}{l}-0.730 \\
(0.341)\end{array}$ & $\begin{array}{l}- \\
-\end{array}$ \\
\hline R \& D intensity & $\begin{array}{l}0.372 \\
(0.622)\end{array}$ & $\begin{array}{l}0.277 \\
(1.282)\end{array}$ & $\begin{array}{l}0.841 \\
(0.569)\end{array}$ \\
\hline Firm size (log) & $\begin{array}{l}0.085^{* * *} \\
(0.039)\end{array}$ & $\begin{array}{l}0.158^{*} \\
(0.071)\end{array}$ & $\begin{array}{l}0.078 \\
(0.043)\end{array}$ \\
\hline Part of a group & $\begin{array}{l}0.174 \\
(0.077)\end{array}$ & $\begin{array}{l}0.228 \\
(0.125)\end{array}$ & $\begin{array}{l}0.096 \\
(0.086)\end{array}$ \\
\hline IMR (Innovator) & $\begin{array}{l}0.424 \\
(0.327)\end{array}$ & $\begin{array}{l}0.039 \\
(0.565)\end{array}$ & $\begin{array}{l}0.123 \\
(0.376)\end{array}$ \\
\hline Intercept & $\begin{array}{l}-0.687 \\
(0.455)\end{array}$ & $\begin{array}{l}-0.781 \\
(0.713)\end{array}$ & $\begin{array}{l}-0.173 \\
(0.562)\end{array}$ \\
\hline Industry dummies & Included & Included & Included \\
\hline $\begin{array}{l}\text { Shea (first-stage) } \\
\text { partial R2 } \\
\text { (breadth) }\end{array}$ & 0.03 & 0.06 & 0.05 \\
\hline $\begin{array}{l}\text { Shea (first-stage) } \\
\text { partial R2 } \\
\text { (depth) }\end{array}$ & 0.02 & 0.05 & 0.03 \\
\hline $\begin{array}{l}\text { Hansen J statistic } \\
\quad \text { (p-value) }\end{array}$ & $10.83(0.54)$ & $8.15(0.83)$ & $10.20(0.68)$ \\
\hline No of obs. & 1133 & 467 & 666 \\
\hline
\end{tabular}

Notes: Robust standard errors in parentheses.

${ }^{*} \mathrm{p}<0.1$.

${ }^{* * *} \mathrm{p}<0.05$

**** $\mathrm{p}<0.01$.

Table 3. Model 1 is estimated on the entire sample of innovating firms, while the results of the estimations on the sub-samples of incremental and radical innovators, are given in models 2 and 3.

In model 1, external search breadth has a positive and significant $(p<0.01)$ estimated coefficient, while that of depth is not significant. This provides support for H1a but not for H2a. Furthermore, the results in Table 3, model 1, indicate support for hypotheses 3a, and 4a as the coefficient on the share of radical innovation is negative and significant $(\mathrm{p}<0.05)$, while that on incremental innovation is positive and significant $(\mathrm{p}<0.05)$.

To test hypotheses 5 and $6 \mathrm{a}$, the model was re-estimated on two sub-samples: model 2 refers to incremental innovators and model 3 refers to radical innovators. In the model estimated on the incremental innovators sub-sample (Table 3, model 3), in line with hypothesis 5 , the coefficient of the variable that measures external search breadth is positive and significant ( $\mathrm{p}<0.01)$, the one on the variable depth is not significant. In support of hypothesis $6 \mathrm{a}$, the coefficient of the variable that measures external search depth is positive and significant $(\mathrm{p}<$ 0.01 ) in the model estimated on the radical innovators sub-sample (Table 3, model 2), while the coefficient of the variable breadth is not significant.

The empirical results of the instrumental variables GMM regression models regarding the use of the informal appropriation mechanisms, relevant for hypotheses $1 \mathrm{~b}, 2 \mathrm{~b}, 3 \mathrm{~b}, 4 \mathrm{~b}$ and $6 \mathrm{~b}$, are reported in Table 4, models 4 and 5 . Model 6 is only presented to give a complete overview of the results but as such it is not relevant for the hypotheses that are tested in this paper.

In model 4, both external search breadth and depth have a positive and significant (at the 5\% level). Jointly with results from model 1 , these results provide support for the general understanding that the openness of firms, in terms of both external search breadth and depth, has a positive impact on their propensity to use formal and informal appropriation mechanisms.

The results in Table 4, model 4, indicate no support for hypothesis $3 \mathrm{~b}$, as the coefficient on the share of radical innovation is not statistically significant. There is also no support for hypothesis $4 \mathrm{~b}$, since the coefficient on the incremental innovation is not significant. However, in line with hypothesis $6 \mathrm{~b}$, the coefficient for the breadth variable is positive and significant $(\mathrm{p}<0.05)$, while the coefficient for the depth variable for radical innovators is insignificant (see Table 4, model 5). These results suggest that the breadth of search openness of radical innovators, rather than their depth, has a positive impact on their use of informal appropriation mechanisms. Surprisingly, no impact of either breadth or depth of search openness for incremental innovators on informal appropriation mechanisms was hypothesized, the estimation produces similar result for these incremental innovators (see Table 4, model 6).

Among the control variables, firm size is positive and significant in models 1-3, (but not in 4-6) suggesting that larger firms are more likely to pursue formal appropriation strategies compared to smaller firms. One explanation of the significantly positive size coefficient in the formal appropriation models may be that smaller firms face affordability issues regarding their decision to use formal and informal 
Table 4

Instrumental variables analysis of firms' use of informal appropriation mechanisms.

\begin{tabular}{|c|c|c|c|}
\hline & $\begin{array}{l}\text { Model } 4 \\
\text { All firms } \\
\text { H1b, H2b, } \\
\text { H3b, H4b }\end{array}$ & $\begin{array}{l}\text { Model } 5 \\
\text { Radical } \\
\text { innovators H6b }\end{array}$ & $\begin{array}{l}\text { Model } 6 \\
\text { Incremental } \\
\text { innovators Not } \\
\text { hypothesized }\end{array}$ \\
\hline $\begin{array}{l}\text { External search } \\
\text { breadth }\end{array}$ & $\begin{array}{l}0.324^{* * *} \\
(0.128)\end{array}$ & $\begin{array}{l}0.264^{* * *} \\
(0.119)\end{array}$ & $\begin{array}{l}0.526^{* * * *} \\
(0.125)\end{array}$ \\
\hline $\begin{array}{l}\text { External search } \\
\quad \text { depth }\end{array}$ & $\begin{array}{l}1.168^{\text {*** }} \\
(0.605)\end{array}$ & $\begin{array}{l}0.642 \\
(0.486)\end{array}$ & $\begin{array}{l}0.196 \\
(0.683)\end{array}$ \\
\hline $\begin{array}{l}\text { Share of } \\
\text { incremental } \\
\text { innovation }\end{array}$ & $\begin{array}{l}0.168 \\
(0.182)\end{array}$ & $\begin{array}{l}0.472^{*} \\
(0.265)\end{array}$ & $\begin{array}{l}-0.213 \\
(0.282)\end{array}$ \\
\hline $\begin{array}{c}\text { Share of radical } \\
\text { innovation }\end{array}$ & $\begin{array}{l}0.026 \\
(0.350)\end{array}$ & $\begin{array}{l}-0.535 \\
(0.433)\end{array}$ & $\begin{array}{l}- \\
-\end{array}$ \\
\hline $\mathrm{R} \& \mathrm{D}$ intensity & $\begin{array}{l}0.503 \\
(0.844)\end{array}$ & $\begin{array}{l}-0.664 \\
(1.476)\end{array}$ & $\begin{array}{l}1.927^{* * *} \\
(0.794)\end{array}$ \\
\hline Firm size (log) & $\begin{array}{l}0.015 \\
(0.052)\end{array}$ & $\begin{array}{l}-0.034 \\
(0.071)\end{array}$ & $\begin{array}{l}0.065 \\
(0.060)\end{array}$ \\
\hline Part of a group & $\begin{array}{l}0.154 \\
(0.103)\end{array}$ & $\begin{array}{l}0.073 \\
(0.144)\end{array}$ & $\begin{array}{l}0.237 \\
(0.120)\end{array}$ \\
\hline IMR (Innovator) & $\begin{array}{l}0.322 \\
(0.437)\end{array}$ & $\begin{array}{l}0.151 \\
(0.590)\end{array}$ & $\begin{array}{l}0.670 \\
(0.530)\end{array}$ \\
\hline Intercept & $\begin{array}{l}-0.255 \\
(0.606)\end{array}$ & $\begin{array}{l}0.265 \\
(0.847)\end{array}$ & $\begin{array}{l}-0.767 \\
(0.788)\end{array}$ \\
\hline Industry dummies & Included & Included & Included \\
\hline $\begin{array}{c}\text { Shea (first-stage) } \\
\text { partial R2 } \\
\text { (breadth) }\end{array}$ & 0.03 & 0.06 & 0.05 \\
\hline $\begin{array}{l}\text { Shea (first-stage) } \\
\text { partial R2 } \\
\text { (depth) }\end{array}$ & 0.02 & 0.03 & 0.03 \\
\hline $\begin{array}{l}\text { Hansen J statistic } \\
\quad \text { (p-value) }\end{array}$ & $4.76(0.98)$ & $4.21(0.99)$ & $6.93(0.91)$ \\
\hline No of obs. & 1133 & 467 & 666 \\
\hline
\end{tabular}

Notes: Robust standard errors in parentheses.

${ }^{*} \mathrm{p}<0.1$.

${ }^{* * *} \mathrm{p}<0.05$

$\mathrm{p}<0.01$.

mechanisms. In particular, smaller firms may not be in an ideal position concerning formal intellectual property rights, particularly given the high legal costs (Rothwell and Dodgson, 1991). Industry dummies are jointly not significant, and hence the estimated coefficients are not reported for the space reasons.

A number of tests corroborate the validity of the IV approach. Under-identification tests revealed identification for the breadth equations: the Kleinberg-Paap Wald test rejected the null hypothesis of under-identification $(p<0.05)$ and marginally for the depth equation, while the Sargan test did not reject the over-identification restriction $(p>0.10)$ for the first-stage equations. The $F$-test based on Shea's partial $\mathrm{R}^{2}$ of the first-stage regressions was significant $(p<0.01)$ for both sets of analysis, indicating the appropriateness of the instruments.

As a robustness check, the models were re-run on an unbalanced longitudinal dataset, constructed from three consecutive surveys, covering 2002-2008. These results are consistent with the main results regarding the use of formal appropriation mechanisms. This additional analysis is reported in the Appendix A.

\section{Discussion}

Acknowledging the increasing strategic relevance of appropriation mechanisms (Pisano and Teece, 2007; Somaya, 2012), this study analysed the influence of the degree of openness and innovativeness on the use of both formal and informal appropriation mechanisms. Table 5 summarizes the main results.

\subsection{Theoretical implications}

The first research question concerned the general role of openness in innovation and its impact on both formal and informal appropriation mechanisms. A set of baseline hypotheses suggested that external search breadth and depth are positively associated with firms' use of both formal and informal appropriation mechanisms. The results of this study mostly support these hypotheses, except for the association between external search depth and formal appropriation mechanisms. This overall empirical support is in line with prior literature, positioned in the domain of open innovation that has assumed a positive connection between openness and appropriation (Laursen and Salter, 2014; Hagedoorn and Zobel, 2015; Zobel et al., 2016). As firms become more open in their innovation processes, they increasingly need to protect their knowledge and prevent potential free-riding via formal and informal mechanisms. Interestingly, informal appropriation mechanisms, such as complexity, secrecy, and lead time, seem to demonstrate a somewhat stronger association with openness in innovation than formal appropriation mechanisms, such as patents, trademarks, copyrights, and design rights. Especially in the context of external search depth, hiding certain parts of the knowledge base via informal appropriation mechanisms, seems to be more relevant (as indicated by a significant positive coefficient of depth on informal appropriation) than knowledge protection and codification via formal appropriation mechanisms (as indicated by an insignificant coefficient of depth on formal appropriation). This finding echoes Hall et al. (2014) who suggest that firms tend to consider informal appropriation mechanisms more important than formal appropriation mechanisms. However, this interpretation needs to be treated with caution, especially since the association between depth and formal appropriation mechanisms does become somewhat significant once multiple waves of the CIS data are considered (see the Appendix A).

The second research question concerned the association between firms' degree of innovativeness and their use of formal and informal appropriation mechanisms. In line with prior literature (Dewar and Dutton, 1986; Schmidt and Calantone, 1998; Garcia and Calantone, 2002), this study differentiates between incremental and radical innovation orientation. On the one hand, there is support with respect to formal appropriation mechanisms that are negatively influenced by a firm's degree of radical innovation orientation and positively influenced by a firm's degree of incremental innovation orientation. Hence, this study confirms some of Anton and Yao (2004) and Zaby's (2010) theoretical propositions that radical innovators, somewhat counterintuitively, actually use less formal appropriation mechanisms. As firms are more radical in their innovation orientation, they want to avoid the disclosure of their knowledge via formal appropriation mechanisms and prevent the re-design of their radical innovations (see also Langinier, 2005; Magazzini et al., 2009; Somaya, 2012). Yet, as the firms' degree of incremental innovativeness increases, formal appropriation mechanisms become relevant for protecting innovations that are close to existing technological knowledge. On the other hand, this study suggests no support with respect to any association between the degree of innovativeness and the use of informal appropriation mechanisms. Neither the degree to which a firm's innovation orientation is radical nor its incremental innovation orientation has any significant association with its use of informal appropriation.

Despite these mixed findings, a firm's degree of innovativeness still matters for both formal and informal appropriation mechanisms. This is highlighted in the findings concerning the third research question that addressed the joint influence of openness and innovativeness on formal and informal appropriation mechanisms. In particular, the results demonstrate significant associations between openness and informal (as well as formal) appropriation mechanisms, once the analysis differentiates between radical and incremental innovators. As hypothesized, for radical innovators it is external search breadth (rather than external search depth) that has a significant positive 
association with the use of informal appropriation mechanisms. When radical innovators search across a broad range of external partners with different backgrounds (e.g. with firms, universities, and technology institutions), it is difficult for partners to acquire knowledge and the risk of unintended appropriation is relatively low. Under these conditions, firms that are active in open innovation and that can be characterized as radical innovators are found to use informal appropriation mechanisms such as secrecy, lead-time, and product complexity. These findings and insights qualify propositions by Zaby (2010) who suggested a positive association between radical innovation and informal appropriation. Complementing prior research, the results of this study suggest that it is not the degree of radical innovation orientation per se that impacts the use of informal appropriation, but that the degree of radical innovation orientation and the firm's external search breadth interact in their influence on the use of informal appropriation mechanisms.

Interestingly, there is also a positive association between external search breadth and informal appropriation mechanisms in the case of incremental innovators. The theoretical framework of this study suggested that for incremental innovators informal appropriation mechanisms are irrelevant, since their innovation knowledge is closely related to the state-of the-art and, therefore, difficult to protect by leadtime, secrecy, or complexity. Yet, the findings seem to suggest that when incremental innovators search broadly across external knowledge sources they still find it useful to implement such informal appropriation mechanisms. Further research is required to identify the underlying mechanisms that explain the association between external search breadth and informal appropriation mechanisms in the context of incremental innovators.

Breadth of search openness is more important for incremental innovators, while depth of search openness is more important for radical innovators for determining their use of formal appropriation mechanisms. It turns out that it is in particular the breadth, rather than the depth of search openness, that generates an appropriation risk for incremental innovators that is countered by formal appropriation mechanisms. Given that the innovative distance between incremental innovators and their partners is already small, increased depth of search openness does not offer any additional motivations for using formal appropriation mechanisms. Oppositely, when radical innovators enter into in-depth search processes across external partners and there is an increased risk of unintended knowledge transfer, appropriation concerns are apparently translated into an increasing use of formal appropriation mechanisms.

In sum, this study suggests that the role of search breadth and depth differs between radical and incremental innovators. This differentiation of firms in terms of both the breadth and depth of their search openness as well as their role as incremental or radical innovators, enables a new and more fine-grained analysis of the degree to which firms use formal and informal appropriation mechanisms. Interestingly the strategic innovative choices - in terms of external search openness and degree of innovativeness - are more relevant for determining firms' use of formal and informal appropriation than external factors such as industry affiliation - or more general firm characteristics, such as size, level of R \& D engagement, and group affiliation.

\subsection{Practical implications}

The findings of this study indicate a number of important managerial implications. First, the results displayed in Table 5 can serve as a helpful template for managers deciding on the firms' use of formal and informal appropriation strategies. The table shows how the openness in innovation and the overall innovativeness of firms constitute important factors in the implementation of formal and informal appropriation mechanisms.

Second, the results are informative for understanding appropriation strategies of competitors and potential partners. The more firms are
Table 5

Summary of relationships between innovative activities and appropriation mechanisms.

\begin{tabular}{|c|c|c|c|}
\hline \multicolumn{2}{|c|}{ Innovative activities } & \multicolumn{2}{|c|}{ Appropriation mechanisms } \\
\hline & & Formal & Informal \\
\hline \multirow[t]{2}{*}{ Search openness } & Search breadth & + & + \\
\hline & Search depth & No association & + \\
\hline \multirow[t]{2}{*}{ Innovative-ness } & $\begin{array}{l}\text { Radical innovation } \\
\text { orientation }\end{array}$ & - & No association \\
\hline & $\begin{array}{l}\text { Incremental } \\
\text { innovation } \\
\text { orientation }\end{array}$ & + & No association \\
\hline \multirow{2}{*}{$\begin{array}{l}\text { Incremental } \\
\text { innovators }\end{array}$} & Search breadth & + & + \\
\hline & Search depth & No association & No association \\
\hline \multirow{2}{*}{$\begin{array}{l}\text { Radical } \\
\quad \text { innovators }\end{array}$} & Search breadth & No association & + \\
\hline & Search depth & + & No association \\
\hline
\end{tabular}

characterized as radical innovators, i.e. highly innovative firms, the more they will find that their peers, i.e. firms with similar characteristics, use patents, trademarks, copyrights, and design rights to protect their new products and technologies when they enter into close cooperation with innovation partners. Given the appropriation risks that come with in-depth cooperation, the use of these formal appropriation mechanisms seems necessary for radical innovators to protect their innovative capabilities. For these radical innovators, appropriation risks seem lower when they search broadly across a large number of different partners but without in-depth joint efforts. Under such conditions, radical innovators will find that many of their peers prefer informal appropriation mechanisms, such as secrecy, lead-time, and complexity of their products or processes to protect their innovative capabilities. For incremental innovators, firms that play a very moderate role as innovators, the results of this study suggest that in-depth search might not be that relevant as there is little in their limited innovative capabilities that warrant in-depth cooperation. However, when incremental innovators search across a large range of partners at modest levels of cooperation intensity, using formal appropriation mechanisms (patents, trademarks, copyrights, and design rights) and to a lesser degree also informal appropriation mechanisms (secrecy, lead-time, and products or processes complexity) seem suitable mechanisms to protect their limited innovative capabilities.

\section{Limitations and conclusions}

Despite these interesting findings, a number of loose ends in the conceptual framework and empirical analysis merit a further discussion. First, it needs to be noted that while external search breadth and depth are treated as separate constructs in the conceptual framework, the operationalization of these two variables is not independent. The way that these variables are constructed suggests that only three out of four possible combinations of these two search strategies can be assessed. While combinations of low breadth/low depth, high breadth/low depth, and high breadth/high depth can be captured by the variables used in this study, the combination of low breadth and high depth cannot be assessed. Hence, the analysis at hand cannot fully account for firms that cooperate very intensely with a very low variety of partners. Future research needs to shed some light on this specific category of firms.

Second, while the analysis suggests that characteristics of the innovation process impact firms' use of formal and informal appropriation mechanisms, the authors do acknowledge that both independent and dependent variables are strategic choice variables, which implies that the reverse causality cannot be fully ruled out.

Furthermore, the CIS data does not enable us to discover a 
chronological pattern in the use of e.g. informal appropriation mechanisms in early stages of innovative activities and formal appropriation mechanisms for later stage innovative activities. Additionally, given data restrictions, this study cannot assess the actual innovative capabilities of the various open innovation partners of the focal firms in this sample. A more thorough understanding of the capabilities of these partners is, however, necessary to better assess the use of both formal and informal appropriation mechanisms under various conditions. Beyond capabilities, there are a number of other partner characteristics that would be of interest in the context of this study. For instance, partner firm size may be influential in determining a focal firm's implementation of appropriation mechanisms. While there is often interdependence between small and large firms during the evolution of technologies (e.g. Dodgson and Rothwell, 1994), size differences between partners may also aggravate appropriation concerns, especially from the perspective of the smaller firm. Furthermore, appropriation hazards may depend on the level of absorptive capacity of partners (Muscio, 2007). It may be likely that the greater the absorptive capacity of its partner, the more concerned would the focal firm be about implementing informal rather than formal appropriation mechanisms.

Finally, it would be of interest to investigate to what extent firms adapt their use of both formal and informal appropriation mechanisms according to different stages of the innovation process. For instance, do preferences with respect to formal and informal appropriation mechanisms differ in early research stages of the innovation funnel as compared to later stages of the development phase? In that context, a more dynamic perspective on the interaction between innovation and appropriation mechanisms could benefit from a broader understanding of stages of innovation in terms of technological paradigms (Dosi, 1982; Nelson and Winter, 1982) or technology life cycles (Stolwijk et al., 2012). As suggested by Narula (2001) such a detailed understanding of different stages of paradigmatic evolution and the position of firms in that evolution can inform the perception of the relevance of alternative forms of external innovative inputs and the use of various appropriation mechanisms. Finally, normative implications of different combinations of appropriation mechanisms, selected under different conditions, remain to be investigated.

To conclude, the analysis presented in this paper generates a number of interesting new insights. It demonstrates how two specific facets of the overall innovation activities of firms (i.e. openness and degree of innovativeness) influence firms' implementation of formal and informal appropriation mechanisms. These findings suggest a more detailed insight regarding appropriation strategies and management of appropriation mechanisms by firms and how these are influenced by firms' strategic behaviours. In addition, this study contributes to the open innovation literature by developing a more differentiated picture of how firms manage appropriation mechanisms when engaging in open innovation activities. In particular, it suggests that the different types of search openness (i.e. breadth and depth) and different levels of innovativeness (i.e. incremental versus radical) intertwine in shaping a firm's implementation of formal and informal appropriation mechanisms.

\section{Appendix A}

The characteristics of this larger sample are similar to the ones reported for the main analysis. 38.67 per cent of the firms in the longitudinal sample have used formal appropriation mechanisms. Among these firms, 69.55 per cent used patents, by far the most popular appropriation mechanism, followed by trademarks (54.99 per cent), design rights (22.86 per cent), and copyrights (12.52 per cent). Among those firms that used formal appropriation mechanisms, 43.68 per cent used more than one appropriation mechanism, and 3.37 per cent used all four formal appropriation mechanisms (Table A1).
Table A1

Instrumental variables analysis of firms' propensity to use formal appropriation mechanisms, 2002-2008.

\begin{tabular}{|c|c|c|c|}
\hline & $\begin{array}{l}\text { Model 1 } \\
\text { H1a, H2a, } \\
\text { H3a }\end{array}$ & $\begin{array}{l}\text { Model } 2 \\
\text { Incremental } \\
\text { innovators H4 }\end{array}$ & $\begin{array}{l}\text { Model } 3 \\
\text { Radical } \\
\text { innovators } \mathrm{H} 5 \mathrm{a}\end{array}$ \\
\hline $\begin{array}{l}\text { External search } \\
\text { breadth }\end{array}$ & $\begin{array}{l}0.156^{* * * *} \\
(0.050)\end{array}$ & $\begin{array}{l}0.164^{* * * *} \\
(0.048)\end{array}$ & $\begin{array}{l}-0.049 \\
(0.054)\end{array}$ \\
\hline $\begin{array}{l}\text { External search } \\
\quad \text { depth }\end{array}$ & $\begin{array}{l}0.687^{*} \\
(0.390)\end{array}$ & $\begin{array}{l}0.481 \\
(0.336)\end{array}$ & $\begin{array}{l}0.693^{* * *} \\
(0.343)\end{array}$ \\
\hline $\begin{array}{l}\text { Share of incremental } \\
\text { innovation }\end{array}$ & $\begin{array}{l}0.074 \\
(0.141)\end{array}$ & $\begin{array}{l}0.064 \\
(0.132)\end{array}$ & $\begin{array}{l}0.443^{*} \\
(0.252)\end{array}$ \\
\hline $\begin{array}{l}\text { Share of radical } \\
\text { innovation }\end{array}$ & $\begin{array}{l}-0.103 \\
(0.218)\end{array}$ & $\begin{array}{l}- \\
-\end{array}$ & $\begin{array}{l}-0.095 \\
(0.186)\end{array}$ \\
\hline $\mathrm{R} \& \mathrm{D}$ intensity & $\begin{array}{l}-0.274 \\
(0.870)\end{array}$ & $\begin{array}{l}-0.218 \\
(1.079)\end{array}$ & $\begin{array}{l}2.874^{* * *} \\
(1.121)\end{array}$ \\
\hline Firm size (log) & $\begin{array}{l}-0.012 \\
(0.051)\end{array}$ & $\begin{array}{l}-0.017 \\
(0.051)\end{array}$ & $\begin{array}{l}0.231 \\
(0.066)\end{array}$ \\
\hline MNE dummy & $\begin{array}{l}-0.071 \\
(0.110)\end{array}$ & $\begin{array}{l}0.065 \\
(0.118)\end{array}$ & $\begin{array}{l}-0.159 \\
(0.174)\end{array}$ \\
\hline $\begin{array}{l}\text { Domestic group } \\
\text { dummy }\end{array}$ & $\begin{array}{l}0.020 \\
(0.112)\end{array}$ & $\begin{array}{l}0.128 \\
(0.115)\end{array}$ & $\begin{array}{l}-0.029 \\
(0.181)\end{array}$ \\
\hline IMR (Innovator) & $\begin{array}{l}0.332^{*} \\
(0.183)\end{array}$ & $\begin{array}{l}0.394^{*} \\
(0.208)\end{array}$ & $\begin{array}{l}-0.051 \\
(0.255)\end{array}$ \\
\hline Intercept & $\begin{array}{l}-0.830^{* * * *} \\
(0.209)\end{array}$ & $\begin{array}{l}-0.902^{* * * *} \\
(0.241)\end{array}$ & $\begin{array}{l}-1.204^{* * * *} \\
(0.344)\end{array}$ \\
\hline Year dummies & Included & Included & Included \\
\hline Industry dummies & Included & Included & Included \\
\hline $\begin{array}{c}\text { Shea (first-stage) } \\
\text { partial R2 } \\
\text { (breadth) }\end{array}$ & 0.02 & 0.04 & 0.04 \\
\hline $\begin{array}{l}\text { Shea (first-stage) } \\
\text { partial R2 } \\
\text { (depth) }\end{array}$ & 0.01 & 0.02 & 0.02 \\
\hline $\begin{array}{l}\text { Hansen } \mathrm{J} \text { statistic } \\
\quad(p \text {-value })\end{array}$ & $15.53(0.34)$ & $12.41(0.57)$ & $15.83(0.39)$ \\
\hline No of obs. & 2149 & 1083 & 1066 \\
\hline
\end{tabular}

Notes: Robust standard errors in parentheses.

${ }^{*} \mathrm{p}<0.1$.

p $<0.05$.

**** $\mathrm{p}<0.01$.

\section{References}

Alexy, O., Criscuolo, P., Salter, A., 2009. Does IP strategy have to cripple open innovation? MIT Sloan Manag. Rev. 51 (1), 71-77.

Anton, J.J., Yao, D.A., 2004. Little patents and big secrets: managing intellectual property. RAND J. Econ. 35, 1-22.

Arundel, A., Kabla, I., 1998. What percentage of innovations are patented? Empirical estimates for European firms. Res. Policy 27, 127-141.

Baum, C.F., Schaffer, M.E., Stillman, S., 2003. Enhanced routines for instrumental variables/GMM estimation and testing. Stata J. 7 (4), 465-506.

Bessen, J., Meurer, M.J., 2008. Patent Failure. Princeton University Press, Princeton, NJ.

Chesbrough, H.W., 2003. Open Innovation: the New Imperative for Creating and Profiting From Technology. Harvard Business School Press, Boston, MA.

Chiang, Y., Hung, K., 2010. Exploring open search strategies and perceived innovation performance from the perspective of inter-organizational knowledge flows. RD Manag. 40 (3), 292-299.

Cohen, W.M., Nelson, R., Walsh, J., 2000. Protecting Their Intellectual Assets Appropriability Conditions and Why U.S. Manufacturing Firms Patent or Not. NBER Working Paper No. 7552

Dahlander, L., Gann, D.M., 2010. How open is innovation? Res. Policy 39, 699-709.

Dewar, R.D., Dutton, J.E., 1986. The adoption of radical and incremental innovations: an empirical analysis. Manag. Sci. 32, 1422-1433.

Dodgson, M., Rothwell, R., 1994. Innovation and size of firm. In: Dodgson, M., Rothwell, R. (Eds.), The Handbook of Industrial Innovation. Edward Elgar, Cheltenham.

Dosi, G., 1982. Technological paradigms and technological trajectories: a suggested interpretation of the determinants and and directions of technical change. Res. Policy 11, 147-162.

Drechsler, W., Natter, M., 2012. Understanding a firm's openness decisions in innovation. J. Bus. Res. 65, 438-445.

Dubiansky, J., 2006. The role of patents in fostering open innovation. Va. J. Law Technol. $11(7), 1-36$.

Eurostat and OECD, 2005. Oslo Manual: Guidelines for Collecting and Interpreting Innovation Data, 3rd Edition, Paris. 
Frankort, H.T.W., Hagedoorn, J., Letterie, W., 2012. R\& D partnership portfolios and the inflow of technological knowledge. Ind. Corp. Change 21, 507-537.

Freeman, C., Soete, L., 1997. The Economics of Industrial Innovation. Routledge, London.

Garcia, R., Calantone, R., 2002. A critical look at technology innovation typology and Innovativeness terminology: a literature reviewJ. Prod. Innov. Manag. 19, 110-132.

Garriga, H., von Krogh, G., Spaeth, S., 2013. How constraints and knowledge impact open innovation. Strateg. Manag. J. 34 (9), 1134-1144.

Gomes-Casseres, B., Hagedoorn, J., Jeffe, A., 2006. Do alliances promote knowledge flows? J. Financ. Econ. 80, 5-33.

Graham, S.J.H., Mowery, D.C., 2006. The use of intellectual property in software: implications for open innovation. In: Chesbrough, H.W., Vanhaverbeke, W., West, J. (Eds.), Open innovation: researching a new paradigm. Oxford University Press, Oxford, 109-133.

Hagedoorn, J., Zobel, A.-K., 2015. The role of contracts and intellectual property rights in open innovation. Technol. Anal. Strateg. Manag. 27 (9), 1050-1067.

Hall, B., Ziedonis, R., 2001. The patent paradox revisited: an empirical study of patenting in the U.S. semiconductor industry, 1979-1995. RAND J. Econ. 32, 101-128.

Hall, B., Helmers, C., Rogers, M., Sena, V., 2014. The choice between formal and informal intellectual property: a literature review. J. Econ. Lit. 52 (2), 375-423.

Hannah, D.R., 2005. Should I keep a secret? The effects of trade secret protection procedures on employees' obligations to protect trade secrets. Organ. Sci. 16 (1), $71-84$.

Haunschild, P.R., Miner, A.S., 1997. Modes of interorganizational imitation: the effects of outcome salience and uncertainty. Adm. Sci. Q. 42 (3), 472-500.

Helfat, C.E., Quinn, J.B., 2006. Open innovation: the new imperative for creating and profiting from technology by Henry Chesbrough, Review by: constance E. Helfat \& J. Brian Quinn. Acad. Manag. Perspect. 20 (2), 86-88.

Hsu, D.H., Ziedonis, R.H., 2013. Resources as dual sources of advantage: implications for valuing entrepreneurial -firm patents. Strat. Manag. J., DOI: 10.1002.

Huizingh, E.K.R.E., 2011. Open innovation: state of the art and future perspectives. Technovation 31, 2-9.

Hurmelinna-Laukkanen, P., 2011. Enabling collaborative innovation - knowledge protection for knowledge sharing. Eur. J. Innov. Manag. 14 (3), 303-321.

Hurmelinna, P., Kyläheiko, K., Jauhiainen, T., 2007. The janus face of the appropriability regime in the protection of innovations: theoretical re-appraisal and empirical analysis. Technovation 27, 133-144.

James, S.D., Leiblein, M.J., Lu, S., 2013. How firms capture value from their innovations. J. Manag. 39 (5), 1123-1155.

Kani, M., Motohashi, K., 2012. Understanding the technology market for patents: new insights from licensing survey of Japanese firms. Res. Policy 41, 226-235.

Koput, K.W., 1997. A chaotic model of innovative search: some answers, many questions. Organ. Sci. 8, 528-542.

Köhler, C., Sofka, W., Grimpe, C., 2012. Selective search, sectoral patterns, and the impact on product innovation performance. Res. Policy 41, 1344-1356.

Langinier, C., 2005. Using patents to mislead rivals. Can. J. Econ. 38, 520-545.

Laursen, K., Salter, A., 2006. Open for innovation: the role of openness in explaining innovation performance among U.K. manufacturing firms. Strateg. Manag. J. 27, $131-150$.

Laursen, K., Salter, A., 2014. The paradox of openness: appropriability, external search and collaboration. Res. Policy 43 (5), 867-878.

Lee, S., Park, G., Yoon, B., Park, J., 2010. Open innovation in SMEs - an intermediated network model. Res. Policy 39, 290-300.

Levin, R.C., Klevorik, A.K., Nelson, R.R., Winter, S.G., 1987. Appropriating the returns from industrial research and development. Brook. Pap. Econ. Act. 3, 783-820.

Liebeskind, J., 1997. Keeping organizational secrets: protective institutional mechanisms and their costs. Ind. Corp. Change 6, 623-663.

Luoma, T., Paasi, J., Valkokari, K., 2010. Intellectual property in inter-organisational relationships - findings from an interview study. Int. J. Innov. Manag. 14 (3), 399-414.

Magazzini, L., Pammolli, F., Riccaboni, M., Rossi, M.A., 2009. Patent disclosure and R\& D competition in pharmaceuticals. Econ. Innov. New Technol. 18, 467-486.

March, J.G., 1988. Decisions and Organizations. Blackwell, New York.

Milesi, D., Petelski, N., Verre, V., 2013. Innovation and appropriation mechanisms: evidence from Argentine microdata. Technovation 33, 78-87.

Mortara, L., Minshall, T., 2011. How do large multinational companies implement open innovation? Technovation 31, 586-597.

Mowery, D.C., Oxley, J.E., Silverman, B.S., 1998. Technological overlap and interfirm cooperation: implications for the resource-based view of the firm. Res. Policy 27, $507-523$.

Muscio, A., 2007. The impact of absorptive capacity on SMEs collaboration. Econ. Innov. New Technol. 16 (8), 653-668.

Narula, R., 2001. Choosing between internal and non-internal R \& D activities: some technological and economic factors. Technol. Anal. Strateg. Manag. 13, 365-387.

Narula, R., 2004. R \& D collaboration by SMEs: new opportunities and limitations in the face of globalization. Technovation 24, 153-161.

Narula R., Zanfei, Z., 2003. Globalisation of Innovation: The Role of Multinational Enterprises. DRUID Working Paper No 03-15

Nelson, R.R., Winter, S.G., 1982. An Evolutionary Theory of Economic Change. Harvard University Press, Cambridge (MA).

Neuhaeusler, P., 2012. The use of patents and informal appropriation mechanisms differences between sectors and among companies. Technovation 32, 681-693.

Organisation for Economic Co-operation and Development, 1997; 2005. Oslo manual. OECD, Paris

Pénin, J., Hussler, C., Burger-Helmchen, T., 2011. New shapes and new stakes: a portrait of open innovation as a promising phenomenon. J. Innov. Econ. 7, 11-29.

Pisano, G., 2006. Profiting from innovation and the intellectual property revolution. Res. Policy 35, 1122-1130.

Pisano, G.P., Teece, D.J., 2007. How to capture value from innovation: shaping intellectual property and industry architecture. Calif. Manag. Rev. 50 (1), 278-295.

Rothwell, R., Dodgson, M., 1991. External linkages and innovation in small and mediumsized enterprises. R \& D Manag. 21 (2), 125-137.

Salge, T.O., Farchi, T., Barrett, M.I., Dopson, S., 2013. When does search openness really matter? A contingency study of health-care innovation projects. J. Prod. Innov. Manag. 30, 4.

Sandulli, F., Chesbrough, H., 2009. The Two Faces of Open Business Models. Working Paper Available at SSRN: 〈http://ssrn.com/abstract=1325682〉

Schmidt, J.B., Calantone, R.J., 1998. Are really new product development projects harder to shut down? J. Prod. Innov. Manag. 15, 111-123.

Somaya, D., 2012. Patent strategy and management: an integrative review and research agenda. J. Manag. 38, 1084-1114.

Stock, J.H., Wright, J.H., 2000. GMM with Weak Identification. Econometrica 68 (5), 1055-1096.

Stolwijk, C.C., Vanhaverbeke, W.P., Ortt, J.R., Pieters, M.W., Den Hartigh, E., Van Beers, C., 2012. The effect of internal and external technology sourcing on firm performance throughout the technology life cycle. Technol. Anal. Strateg. Manag. 24, 1013-1028.

Tidd, J., Bessant, J., Pavitt, K., 2005. Managing Innovation: Integrating Technological, Market and Organizational Change. John Wiley \& Sons, Chichester.

Van de Vrande, V., Lemmens, C., Vanhaverbeke, W., 2006. Choosing governance modes for external technology sourcing. R \& D Manag. 36 (3), 347-363.

Zaby, A.K., 2010. Losing the lead: the patenting decision in the light of the disclosure requirement. Econ. Innov. New Technol. 19, 147-164.

Zobel, A.-K., Balsmeier, B., Chesbrough, H., 2016. Does patenting help or hinder open innovation? Evidence from new entrants in the solar industry. Ind. Corp. Chang. 25 (2), 307-331. 